\title{
Diabetes in the KK Mouse
}

\author{
W.E. DuLIN and B.M. Wrse
}

Diabetes Research, The Upjohn Company, Kalamazoo, Michigan, USA

Summary. Glucose tolerance was abnormal in many male KK mice studied although fasting blood sugars were generally normal. Glucosuria of KK mice was intermittent and nonfasting blood sugar was elevated in some. Plasma insulin of nonfasted KK mice was $10-100$ times that of nondiabetic mice and pancreatic insulin was $50 \%$ higher than that of control mice. The diaphragm and fat pads of KK mice were insensitive to insulin in vitro. The baseline glucose uptake by diaphragm muscles of KK mice was normal, whereas baseline glucose oxidation by adipose tissue was significantly lower in tissue from $\mathrm{KK}$ mice. Limited diet lowers plasma insulin and body weight and restores the adipose tissue sensitivity to insulin. It is postulated that diabetes in the KK mouse is due to decreased sensitivity of fat and muscle to endogenous insulin and to increased food intake which results in an increased demand for insulin. The pancreas responds to this demand by increased insulin secretion and elevated plasma insulin, and as this condition continues, islet hypertrophy results. Continued inbreeding of $\mathrm{KK}$ mice produced animals with fewer abnormalities. Fourth to seventh generation animals derived from inbreeding offspring from KK $\times$ C57 BL/6J mice exhibited relatively large numbers of abnormal animals.

\section{Le diabète de la souris $K K$}

Résumé. La tolérance au glucose est anormale chez beaucoup de souris mâles $\mathrm{KK}$ bien que le taux du sucre sanguin à jeun soit généralement normal. La glucosurie des souris KK est intermittente et le sucre sanguin des souris non soumises au jeûne est élevé chez certaines d'entre elles. Le taux d'insuline plasmatique des souris KK non soumises au jeûne est 10 à 100 fois plus élevé que celui des souris non-diabétiques et l'insuline pancréatique est $50 \%$ plus élevée que celle des souris témoins. Le diaphragme et le tissu adipeux des souris KK sont insensibles à l'insuline in vitro, la captation de base du glucose par le muscle diaphragmatique des souris KK est normale tandis que l'oxydation do base du glucose par le tissu adipeux est significativement plus basse dans le tissu obtenu des souris KK. Un régime calorique limité abaisse le taux d'insuline plasmatique et le poids corporel; de même qu'il rétablit une sensibilité normale du tissu adipeux à l'insuline. Il est postulé que le diabète des souris KK est dû à une diminution de la sensibilité du tissu adipeux et du muscle à l'insuline endogène et à une augmentation de la prise alimentaire qui a pour résultat une augmentation de la demande en insuline. Le pancréas répond à cette demande par une augmentation de la sécrétion d'insuline et par des taux insuliniques élevés et, pour autant que ces conditions persistent, une hyperthrophie des îlots de Langerhans en résulte. La reproduction consanguine des souris KK a produit des animaux présentant seulement quelques anomalies. Les animaux de la 4 e jusqu’à la 7 e génération dérivés de souche consanguine KK $\times \mathrm{C} 57 \mathrm{BL} / 6 \mathrm{~J}$ présentent un nombre relativement grand d'animaux anormaux.

\section{Diabetes bei der KK-Maus}

Zusammenfassung. Trotz gegenüber der Norm um $50 \%$ erhöhtem Pankreasinsulingehalt und 10-100-fach erhöhter Plasmainsulinkonzentration zeigten die KKMäuse der untersuchten Population intermittierende Glykosurie. Bei zahlreichen Tieren war die Glucosetoleranz trotz normaler Nüchternblutzuckerwerte vermindert. In vitro sprachen weder das Zwerchfell noch das epididymale Fettgewebe der KK-Mäuse auf Insulin an. In Abwesenheit von Insulin war die Glucoseaufnahme der Zwerchfellmuskeln normal, wogegen die Glucoseoxidation im Fettgewebe von KK-Mäusen gegenüber der Norm deutlich erniedrigt war. Kalorienrestriktion hatte ein $\mathrm{Ab}$ sinken der Plasmainsulin-Konzentrationen und des Körpergewichts zur Folge und stellte die Insulinempfindlichkeit des Fettgewebes wieder her. Die Autoren nehmen an, daß der Diabetes der KK-Maus auf eine Verminderung der peripheren Insulinempfindlichkeit sowie übermäßige Calorienaufnahme zurückzuführen sei. Die Hyperinsulinemie und die Hypertrophie der Langerhans'schen Inseln des Pankreas werden als Konsequenzen des erhöhten Insulinbedarfs aufgefaßt. Kontinuierliche Inzucht von KKMüusen vermindert die Häufigkeit von Stoffwechselanomalien, dagegen wurde sie durch Kreuzung von KK-Mäusen mit einem Stamm von normalen Tieren ab der 4 . Generation deutlich gesteigert.

Key-words: Spontaneous diabetes, KK mice, insulin, resistance to insulin, diet and sensitivity to insulin.

\section{Introduction}

The KK strain of mouse was one of a series developed by Kondo [4] and some of the characteristics of diabetes in this strain have been described by Nakamura $[7,6,8]$. It was concluded by Nakamura [8] that the inheritance of diabetes in this mouse was probably polygenic. However, Butler [1] has postulated that diabetes in the $\mathrm{KK}$ mouse is the result of a single dominant gene with reduced penetrance which may be a result of a recessive modifier gene. It should be emphasized the genetics of diabetes in the $\mathrm{KK}$ mouse is not completely understood. Due to the possible com- plexity of the mode of inheritance and variation in degree of homozygosity of genetic factors responsible for the abnormalities in this strain of mouse, one finds considerable variation in body weights, plasma insulins, blood sugars and other endpoints characteristically used in defining the diabetic syndrome. Because of this wide variation, we have arbitrarily chosen those KK mice for study which were obese (body weight of greater than $40 \mathrm{~g}$ ) and which had plasma insulins of at least twice normal.

This paper describes studies on a variety of physiological and biochemical parameters of the KK mouse and the effects of limiting diet. 


\section{Methods}

All KK mice used in these studies were males raised from the Upjohn colony of the KK mouse derived from the breeding stock obtained from the Central Laboratories for Experimental Animals in Japan. Several types of nondiabetic animals have been used for comparison and these include Upjohn Rockland, C57 $\mathrm{BL} / \mathbf{6 J}$ and CBAJ. These nondiabetic animals have shown similar results except some (CBAJ) had slightly higher body weights and plasma insulins. The C57 BL/6J's and CBAJ's were obtained from the Jackson Laboratories in Bar Harbor, Maine. In all cases nondiabetic animals were matched with $\mathrm{KK}$ mice so that they were of comparable age and sex. Food in all cases

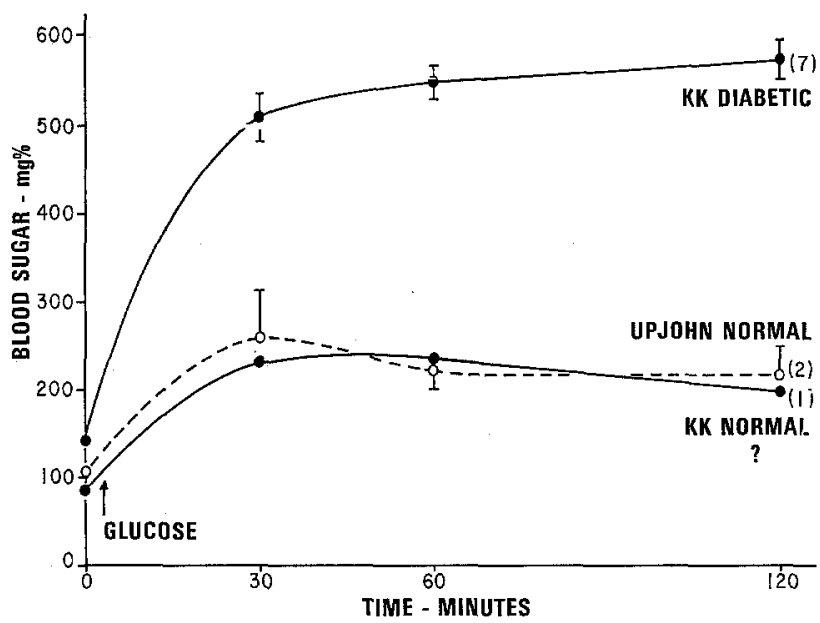

Fig. 1. Glucose tolerance of KK and Upjohn mice follow ing $2 \mathrm{~g} / \mathrm{kg}$ of glucose intraperitoneally

$\mathrm{I}=$ Standard error of mean; $(\quad)=$ Number of animals. were also obtained from the orbital sinus [9] at 30,60 and 120 min following injection of glucose. In others, blood sugars and plasma insulins were measured $2 \mathrm{~h}$ following a $2 \mathrm{~g} / \mathrm{kg}$ intraperitoneal glucose load. Blood sugars in all cases were measured by the micro AutoAnalyzer method. Plasma insulins were determined by a double antibody method [5] as described previously [2] and pancreatic insulin was measured on several dilutions of an acid alcohol extract of the pancreas by the double antibody procedure. Food intake was measured by an inexact method and no attempts were made to collect wasted food since it was assumed that the animals would waste an equivalent percentage of food. Food was measured on the individual animals which had been placed separately in small compartments produced by stainless steel dividers in plastic cages. Food was measured at intervals of $4-5$ days by differences in initial and final weight.

Adipose tissue response to insulin was studied by described methods [3] in which glucose-1-14 $\mathrm{C}$ oxidation by epididymal adipose tissue was studied in vitro over a $90-\mathrm{min}$ period. Glucose uptake by cut diaphragm muscle was measured in vitro following incubation for $90 \mathrm{~min}[10]$. Insulin response of diaphragm was determined by incubating whole diaphragms in the presence

Table 1. Food intake of $C 57 B L / 6 J$ and $K K$ mice. Age at start of study $6-8$ mo. Duration of measurements 4 mo

\begin{tabular}{lll}
\hline No. & Type mouse & $\begin{array}{l}\text { Average daily food intake } \\
(\mathrm{g})\end{array}$ \\
\hline 13 & C57BL/6J & $2.4 \pm 0.01$ \\
12 & KK & $3.4 \pm 0.01^{\mathrm{a}}$ \\
\hline
\end{tabular}

$\mathrm{a}=P<0.01$.

Table 2. Pancreatic insulin of $K K$ mice and Upjohn Rockland mice

\begin{tabular}{lllll}
\hline No. & Type & $\begin{array}{l}\text { Blood sugar } \\
(\mathrm{mg} \%)\end{array}$ & $\begin{array}{l}\text { Plasma insulin } \\
(\mu \mathrm{U} / \mathrm{ml})\end{array}$ & $\begin{array}{l}\text { Pancreatic insulin } \\
(\mathrm{U} / \mathrm{g} \text { tissue })\end{array}$ \\
\hline 5 & Rockland & $168 \pm 19$ & $181 \pm 26$ & $2.90 \pm 0.1$ \\
5 & $\mathrm{KK}$ & $171 \pm 13$ & $488 \pm 203^{\mathrm{b}}$ & $4.37 \pm 0.5^{\mathrm{b}}$ \\
\hline
\end{tabular}

a Age $-31 / 2$ months.

b $P<0.01$.

was Purina Breeder Chow. Some of the mice used in these studies were obtained from inbred offspring derived from KK and C57 BL/6J's crossed in Dr.L. Butler's laboratory, University of Toronto. His mice were made avaiable to our laboratories and inbreeding was continued through the 7 th generation. Throughout these studies these animals are referred to as Toronto mice and they are defined as those of a specific generation.

Glucose tolerance tests were done in animals which were fasted overnight (about $18 \mathrm{~h}$ ) and then injected with glucose at a dose of $2 \mathrm{~g} / \mathrm{kg}$ intraperitoneally immediately following a zero hour blood sample. Bloods and absence of insulin. In the limited diet study, animals were either given food ad libitum or were placed on a limited diet of $2.5 \mathrm{~g}$ of food per day. In studies on limited diet one food pellet of $2.5 \mathrm{~g}$ was given to each animal during a $24-\mathrm{h}$ period. The limited diet was continued for 3 months and at the end of this regime glucose oxidation by adipose tissue, blood sugars and plasma insulins were measured. Blood sugar, plasma insulin and body weights were measured on some Toronto $F_{4}$ generation mice at 3,4 and 9 months of age. Animals from the 6 th and 7 th inbred generations derived from the above cross were obtained in the Upjohn Laboratories by continued inbreeding and 
blood sugars and plasma insulins were measured on these animals at $2-5$ months of age.

\section{Results}

Glucose tolerance of $\mathrm{KK}$ mice was generally decreased although KK mice may exhibit normal tolerance to a glucose load. Although in these studies
$6-8$ months of age at the initiation of the limited diet regime and $10-12$ months of age at the termination (Table 1).

Pancreatic insulin and plasma insulin were significantly elevated in many but not all KK mice (Tables 2 and 6 ). It should be noted that nonfasted blood sugars although not consistently elevated (Tables 2, 3, 4, 7, 8, 10 and 11) were elevated in some animals (Tables 5 ,

Table 3. Plasma insulin and blood sugar of fed and fasted $K K$ and $C 57 B L / 6 J$ mice

\begin{tabular}{|c|c|c|c|c|c|c|}
\hline \multirow[t]{2}{*}{ No. } & \multirow[t]{2}{*}{$\begin{array}{l}\text { Type } \\
\text { animal }\end{array}$} & \multirow[t]{2}{*}{$\begin{array}{l}\text { Body } \\
\text { weight }\end{array}$} & \multicolumn{2}{|c|}{$\begin{array}{l}\text { Blood sugar } \\
\pm \text { S.E. }\end{array}$} & \multicolumn{2}{|c|}{$\begin{array}{l}\text { Plasma insulin } \\
\pm \text { S.E. }\end{array}$} \\
\hline & & & $\overline{\text { fasted }}^{\mathrm{a}}$ & $f e d^{b}$ & fasted & fed. \\
\hline $\begin{array}{l}26 \\
17\end{array}$ & $\begin{array}{l}\mathrm{C} 57 \mathrm{BL} / 6 \mathrm{~J} \\
\mathrm{KK}\end{array}$ & $\begin{array}{l}27 \pm 0.6 \\
47 \pm 1.4^{d}\end{array}$ & $\begin{array}{r}87 \pm 3 \\
104 \pm 4\end{array}$ & $\begin{array}{l}174 \pm 3^{\mathrm{c}} \\
160 \pm 5^{\mathrm{c}}\end{array}$ & $\begin{array}{l}16 \pm 2 \\
52 \pm 8\end{array}$ & $\begin{array}{r}52 \pm 3^{\mathrm{c}} \\
219 \pm 43^{\mathrm{c}}\end{array}$ \\
\hline
\end{tabular}

Table 4. Blood sugars and plasma insulins of $K K$ and $C 57 B L / 6 J$ mice when fed or during 2.h I.P. glucose (2 g/kg) tolerance test (GTT)

\begin{tabular}{|c|c|c|c|c|c|c|c|}
\hline \multirow[t]{2}{*}{ No. } & \multirow{2}{*}{$\begin{array}{l}\text { Type } \\
\text { animal }\end{array}$} & \multicolumn{2}{|c|}{ Body weight } & \multicolumn{2}{|l|}{ Fed } & \multicolumn{2}{|l|}{ 2-h GTT } \\
\hline & & Fasted & Fed & $\begin{array}{l}\text { Blood } \\
\text { sugar }\end{array}$ & Insulin & $\begin{array}{l}\text { Blood } \\
\text { sugar }\end{array}$ & Insulin \\
\hline & & \multicolumn{6}{|c|}{ Young animals (21/2-31/2 months) } \\
\hline $\begin{array}{l}12 \\
11\end{array}$ & $\begin{array}{l}\mathrm{C} 57 \mathrm{BL} / 6 \mathrm{~J} \\
\mathrm{KK}\end{array}$ & $\begin{array}{l}23 \pm 0.3 \\
29 \pm 1.1^{\mathrm{a}}\end{array}$ & $\begin{array}{l}29 \pm 0.5 \\
36 \pm 1.7^{\mathrm{a}}\end{array}$ & $\begin{array}{l}166 \pm 5 \\
153 \pm 8\end{array}$ & $\begin{array}{l}31 \pm 2 \\
42 \pm 6\end{array}$ & $\begin{array}{l}124 \pm 5 \\
132 \pm 5\end{array}$ & $\begin{array}{l}38 \pm 4 \\
46 \pm 5\end{array}$ \\
\hline & & \multicolumn{6}{|c|}{ Older animals ( $>5$ months) } \\
\hline $\begin{array}{r}8 \\
17\end{array}$ & $\begin{array}{l}\text { C57BL/6J } \\
\text { KK }\end{array}$ & - & $\begin{array}{l}30 \pm 1.1 \\
47 \pm 1.4^{\mathrm{a}}\end{array}$ & $\begin{array}{l}158 \pm 6 \\
160 \pm 5\end{array}$ & $\begin{array}{c}48 \pm 4 \\
219 \pm 43^{a}\end{array}$ & $\begin{array}{l}155 \pm 9 \\
191 \pm 9^{b}\end{array}$ & $\begin{array}{l}11 \pm 5 \\
71 \pm 8^{a}\end{array}$ \\
\hline
\end{tabular}

a $P<0.01$ compared to $\mathrm{C} 57 \mathrm{BL} / 6 \mathrm{~J}$.

b $P<0.025$ compared to $\mathrm{C} 57 \mathrm{BL} / 6 \mathrm{~J}$.

Table 5. Blood sugar, plasma insulin and response of adipose tissue to insulin in vitro ${ }^{\mathrm{d}}$

\begin{tabular}{|c|c|c|c|c|c|}
\hline \multirow[t]{2}{*}{$\begin{array}{l}\text { Type } \\
\text { mouse }\end{array}$} & \multirow[t]{2}{*}{ No. } & \multirow[t]{2}{*}{$\begin{array}{l}\text { Blood sugar } \\
(\mathrm{mg} \%)\end{array}$} & \multirow[t]{2}{*}{$\begin{array}{l}\text { Plasma insulin } \\
(\mu \mathrm{U} / \mathrm{ml})\end{array}$} & \multicolumn{2}{|c|}{$\begin{array}{l}\text { Glucose }-1{ }^{14} \mathrm{C} \text { oxidation } \\
\text { (CPM/100 } \mathrm{mg} \text { tissue) }\end{array}$} \\
\hline & & & & No insulin & $\begin{array}{l}\text { Insulin } \\
(250 \mu \mathrm{U} / \mathrm{ml})\end{array}$ \\
\hline $\begin{array}{l}\mathrm{C} 57 \mathrm{BL} / 6 \mathrm{~J} \\
\text { and CBAJ }\end{array}$ & 12 & $167 \pm 4.8$ & $14.7 \pm 1.7$ & $1028 \pm 85^{\mathrm{a}}$ & $2562 \pm 401^{a}, b$ \\
\hline $\mathrm{KK}$ & 10 & $182 \pm 4.4^{\mathrm{c}}$ & $147 \pm 36.9^{\mathrm{c}}$ & $440 \pm 51$ & $572 \pm 57$ \\
\hline
\end{tabular}

a $P<0.01$ compared to $\mathrm{KK}$.

b $P<0.01$ compared to no insulin.

c $P<0.01$ compared to $\mathrm{C} 57 \mathrm{BL} / 6 \mathrm{~J}$ and CBAJ.

d $7-11$ months of age.

fasting blood sugars were only slightly elevated in the KK mice with the abnormal tolerance, the glucose levels remained elevated for at least $2 \mathrm{~h}$ following the I. P. injection of glucose (Fig. 1).

Food intake of $\mathrm{KK}$ mice was elevated significantly when measured over a 4 -month period. The KK mice ate an average of $3.4 \mathrm{~g} /$ day as compared to $2.4 \mathrm{~g} /$ day for the $\mathrm{C} 57 \mathrm{BL} / 6 \mathrm{~J}$ 's. The animals in this study were
6 and 10). Pancreatic insulin was greater than 4 Units/g wet weight of tissue in the KK mice as compared to 2.9 Units/g in the Upjohn Rockland mice. Blood sugar in these animals was essentially normal, whereas plasma insulin was approximately 2.5 times higher than normal (Table 2). Plasma insulins vary considerably in the KK mice although in many it is $>2000 \mu$ Units $/ \mathrm{ml}$ of plasma (Tables 2,5 and 10). Plasma insulin was 
higher in fed $\mathrm{KK}$ or $\mathrm{C} 57 \mathrm{BL} / 6 \mathrm{~J}$ mice than in fasted animals of the same strain. Fasted plasma insulin of KK mice was higher than those of the normal mice (Table 2). Young KK mice frequently have only a slight increase in plasma insulin (Tables 4 and 6) although not always (Table 10). Two hours following a glucose load the plasma insulins of older $\mathrm{KK}$ and nondiabetic mice were similar to levels observed in fasted sugars and plasma insulins were significantly elevated (Table5). In an effort to find the age at which insensitivity of insulin occurs, adipose tissue response to insulin was carried out on tissues from 30-day and 6-week old KK mice. In animals of these ages, the baseline glucose oxidation although higher than that of the tissues from older animals was significantly decreased compared to baseline glucose oxidation by adipose tissue

Table 6. Response of adipose tissue from nonfasted 30 day old $K K$ and $C 57$ mice to insulin in vitro

\begin{tabular}{|c|c|c|c|c|c|c|}
\hline \multirow[t]{2}{*}{$\begin{array}{l}\text { Type } \\
\text { mouse }\end{array}$} & \multirow[t]{2}{*}{ No. } & \multirow{2}{*}{$\begin{array}{l}\text { Blood } \\
\text { sugar } \\
(\mathrm{mg} \%)\end{array}$} & \multirow{2}{*}{$\begin{array}{l}\text { Plasma } \\
\text { insulin } \\
(\mu \mathrm{U} / \mathrm{ml})\end{array}$} & \multirow{2}{*}{$\begin{array}{l}\text { Body } \\
\text { weight } \\
\text { (g) }\end{array}$} & \multicolumn{2}{|c|}{$\begin{array}{l}\text { Glucose } 1{ }^{14} \mathrm{C} \text { oxidation } \\
\left(\mathrm{CPM} \times 10^{3} / 100 \mathrm{mg} \text { tissue }\right)\end{array}$} \\
\hline & & & & & No insulin & Insulin $(250 \mu \mathrm{U} / \mathrm{ml})$ \\
\hline $\mathrm{C} 57$ & 6 & $140 \pm 8$ & $10.3 \pm 1$ & $15 \pm 0.3$ & $54 \pm 12.7$ & $184 \pm 36.8^{\mathrm{c}}$ \\
\hline $\mathbf{K K}$ & 6 & $174 \pm 13^{\mathrm{a}}$ & $20.2 \pm 2^{b}$ & $22 \pm 0.5^{b}$ & $8.6 \pm 0.7^{\mathrm{a}}$ & $29 \pm 6.0^{\mathrm{c}}$ \\
\hline
\end{tabular}

$\mathrm{a}=P<0.05$ between $\mathrm{C} 57$ and $\mathrm{KK}$.

$\mathrm{b}=P<0.01$ between $\mathrm{C} 57$ and $\mathrm{KK}$.

$\mathrm{c}=P<0.01$ between insulin effect on tissues of $\mathrm{KK}$ and $\mathrm{C} 57$ mice.

Table 7. Response of adipose tissue to insulin, body weights, blood sugar and plasma insulin of 6 week old $K K$ and $C 57 B L / 6 J$ mice

\begin{tabular}{|c|c|c|c|c|c|c|}
\hline No. & Туре & $\begin{array}{l}\text { Blood } \\
\text { sugar } \\
(\mathrm{mg} \%)\end{array}$ & $\begin{array}{l}\text { Body } \\
\text { weights } \\
\text { (g) }\end{array}$ & $\begin{array}{l}\text { Plasma } \\
\text { Insulin } \\
(\mu \mathrm{U} / \mathrm{ml})\end{array}$ & \multicolumn{2}{|c|}{$\begin{array}{l}\text { Glucose-1 }{ }^{14} \mathrm{C} \text { oxidation } \\
\left(\mathrm{CPM} / 100 \mathrm{mg} \text { tissue } \times 10^{3}\right)\end{array}$} \\
\hline $\begin{array}{l}6 \\
6\end{array}$ & $\begin{array}{l}\text { C.57 } \\
\text { KK }\end{array}$ & $\begin{array}{l}157 \pm 3 \\
163 \pm 8\end{array}$ & $\begin{array}{l}18 \pm 0.8 \\
26 \pm 0.7 \mathrm{c}\end{array}$ & $\begin{array}{l}18 \pm 1 \\
24 \pm 3\end{array}$ & $\begin{array}{l}0 \text { insulin } \\
17.7 \pm 3.5 \\
5.7 \pm 0.9\end{array}$ & 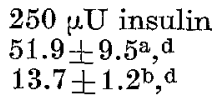 \\
\hline
\end{tabular}

$\mathrm{a}=P<0.01$ between 0 and $250 \mu \mathrm{U}$ insulin.

$\mathrm{b}=P<0.001$ between 0 and $250 \mu \mathrm{U}$ insulin.

$\mathrm{c}=P<0.001$ between $\mathrm{C} 57$ and KK.

$\mathrm{d}=P<0.01$ between insulin effect on tissue of $\mathrm{KK}$ and $\mathrm{C} 57$ mice.

Table 8. FF $A$ of fed and fasted $K K$ and $C 57 B L$ micea

\begin{tabular}{|c|c|c|c|c|c|}
\hline No. & Type & $\begin{array}{l}\text { Blood } \\
\text { sugar }^{b}\end{array}$ & $\begin{array}{l}\text { Plasma } \\
\text { insulin }{ }^{b}\end{array}$ & $\begin{array}{l}\text { Nutritional } \\
\text { state } \\
\text { for FFA }\end{array}$ & $\begin{array}{l}\text { Plasma } \\
\text { FFA } \\
(\mu \mathrm{Eq} / \mathrm{ml})\end{array}$ \\
\hline 6 & $\mathrm{C} 57$ & $166 \pm 10$ & $52 \pm 5$ & Fed & $1331 \pm 106$ \\
\hline 6 & $\mathrm{C} 57$ & $159 \pm 9$ & $48 \pm 5$ & Fasted & $3123+221^{c}$ \\
\hline 6 & KK & $176 \pm 22$ & $499 \pm 213$ & Fod & $1823 \pm 78^{\mathrm{d}}$ \\
\hline 6 & KK & $171 \pm 16$ & $431 \pm 136$ & Fasted & $3090 \pm 283^{c}$ \\
\hline
\end{tabular}

a Age 6-8 months.

b Measured in fed state 2 weeks before FFA study.

c $P<0.01$ compared to fed levels.

d $P<0.01$ comparing fed $\mathrm{KK}$ and $\mathrm{C} 57$.

animals but less than insulin levels of fed mice. In the younger mice plasma insulin levels $2 \mathrm{~h}$ after glucose load were similar to levels observed in fed animals (Tables 3, 4).

Baseline glucose oxidation by epididymal adipose tissue in vitro was significantly decreased in tissues of KK mice of $7-11$ months of age and the addition of $250 \mu$ Units of insulin/ml of buffer did not significantly increase the glucose utilization by adipose tissue of these animals. In these particular animals the blood from C $57 \mathrm{BL} / 6 \mathrm{~J}$ animals. Adipose tissues from both 4 and 6 -week old KK mice exhibited a significant response to insulin although less than that of the tissues from normal animals. Plasma insulins were considerably lower in the 4 and 6 -week old animals than those of older animals although in the younger animals the insulins were higher than those from C57 BL/6J control animals (Tables 5, 6 and 7).

Plasma free fatty acids of fed and fasted KK mice were measured to determine if the elevated insulin of 
KK mice was effective on adipose tissue in vivo. Nonfasting plasma insulins in these KK mice when measured 1 week prior to the free fatty acid study were found to be increased about 10-fold over normal. Unfortunately, no fasted insulins could be obtained in these animals at the time the free fatty acid measurements were carried out since all the blood plasma obtained was required for free fatty acid determinations. Based on data from other animals, fasted plasma insulins would be expected to be reduced considerably as compared to levels in fed animals (Table 4). Plasma FFA of fasted $\mathrm{KK}$ and $\mathrm{C} 57 \mathrm{BL} / 6 \mathrm{~J}$ mice were similar. However, the FFA of fed KK mice were not reduced as much as those of the control mice.

Diaphragm muscles of KK mice were studied for baseline glucose utilization as well as the response to insulin. In these studies baseline glucose uptake by diaphragms of KK mice was essentially equivalent to baseline uptake by tissues from control animals. The response to insulin, however, was significantly reduced in tissues from KK mice (Table 9).

Table 9. Response of diaphragm muscle of $K K$ and $C 5 \% B L / 6 J$ mice to insulin in vitro. Animals $4-10$ months of age

\begin{tabular}{clll}
\hline No. & Type & \multicolumn{2}{l}{$\begin{array}{l}\text { Glucose uptake by diaphragm } \\
(\mathrm{mg} \% / 10 \mathrm{mg} \text { dry weight })\end{array}$} \\
\cline { 3 - 4 } & & 0 Insulin & $2500 \mu \mathrm{U}$ Insulin \\
\hline 10 & $\mathrm{C} 57 \mathrm{BL} / 6 \mathrm{~J}$ & $39.0 \pm 1.3$ & $49.5 \pm 2.8^{\mathrm{a}}$ \\
9 & $\mathrm{KK}$ & $39.2 \pm 1.6$ & $42.3 \pm 3.0$ \\
\hline
\end{tabular}

a $=P<0.01$ between 0 and $2500 \mu \mathrm{U}$ insulin.
Examination of data from several generations of inbred KK mice derived from stock originally obtained from the Central Laboratories for Experimental Animals in Japan showed that as inbreeding was continued plasma insulin and blood sugar values returned towards normal in successive generations (Table 11). For example, examination of the $F_{2}^{\prime}$ generation data shows that 18 of 39 animals exhibited blood sugars greater than $200 \mathrm{mg} \%$ and 19 of the 39 animals (all that were measured) exhibited extremely high plasma insulins. In contrast of a total of eighty $F_{8,9}$ and ${ }_{10}$ animals, none showed blood sugars higher than $200 \mathrm{mg} \%$ and only 2 animals exhibited plasma insulins greater than $100 \mu \mathrm{Units} / \mathrm{ml}$. Therefore, as inbreeding was continued, the number of animals which could be considered abnormal decreased. Of considerable interest was the observation that the blood sugars of Toronto $\mathrm{F}_{4}$ mice derived from inbreeding offspring from $\mathrm{KK} \times$ C57 BL/6J animals were elevated by 4 months and continued to remain elevated over a 9 -month period (Fig. 2). Body weights of the Toronto $F_{4}$ mice were also significantly elevated by 3 months and reached a maximum at 4 months and remained at this elevated level throughout the 9-month period of study (Fig. 3). Plasma insulins of the Toronto $F_{4}$ mice were elevated at 3 months and continued to increase throughout the 9 -months period to an average of over $1600 \mu \mathrm{Units} / \mathrm{ml}$ at 9 months of age (Fig. 4). Animals obtained from continued inbreeding of the $F_{4}$ Toronto mice to the 6 th and 7 th generations show that the elevated blood sugars and plasma insulins were maintained at least through 3 additional generations (Table 12). These

Table 10. Effect of 3 months of limited diet on plasma insulin, blood sugar and glucose-1.11C oxidation by adipose tissue of $K K$ and $C 57 B L / 6 J$ mice

\begin{tabular}{|c|c|c|c|c|c|c|c|c|c|}
\hline \multirow[t]{2}{*}{ No. } & \multirow{2}{*}{$\begin{array}{l}\text { Type } \\
\text { mouse }\end{array}$} & \multicolumn{2}{|c|}{ Body weight } & \multicolumn{2}{|c|}{ Blood sugar (fed) } & \multicolumn{2}{|c|}{ Insulin (fed) } & \multicolumn{2}{|c|}{ Glucose oxidation } \\
\hline & & Initial & Final & Initial & Final & Initial & Final & $\begin{array}{l}\text { CPM } \times 1 \\
0 \text { insulin }\end{array}$ & $\begin{array}{l}3 / g \text { fat } \\
+ \text { insulino }\end{array}$ \\
\hline $\begin{array}{l}5 \\
6\end{array}$ & $\begin{array}{l}\mathrm{C} 57 \mathrm{BL} / 6 \mathrm{~J} \\
\mathrm{KK}\end{array}$ & $\begin{array}{l}\text { Ad lib diet } \\
30.1 \pm 0.4 \\
50.3 \pm 1.1\end{array}$ & $\begin{array}{l}31.7 \pm 0.6 \\
47.8 \pm 1\end{array}$ & $\begin{array}{l}163 \pm 6 \\
162 \pm 8\end{array}$ & $\begin{array}{l}165 \pm 4 \\
181 \pm 5\end{array}$ & $\begin{array}{r}42 \pm \quad 6 \\
307 \pm 190\end{array}$ & $\begin{array}{r}47 \pm 8 \\
172 \pm 44\end{array}$ & $\begin{array}{l}4.5 \pm 1 \\
1.7 \pm 0.2\end{array}$ & $\begin{aligned} & 18.1 \pm 3^{\text {P }} \\
& 2.6 \pm 0.3\end{aligned}$ \\
\hline $\begin{array}{l}6 \\
6\end{array}$ & $\begin{array}{l}\mathrm{C} 57 \mathrm{BL} / 6 \mathrm{~J} \\
\mathrm{KK}\end{array}$ & $\begin{array}{l}\text { Limited die } \\
30.2 \pm 0.5 \\
50.7 \pm 1\end{array}$ & $\begin{array}{l}(2.5 \mathrm{~g} / \mathrm{day}) \\
27.4 \pm 0.6 \\
32.4 \pm 1^{\mathrm{d}}\end{array}$ & $\begin{array}{c}172 \pm 8 \\
153 \pm 15\end{array}$ & $\begin{array}{c}166 \pm 12 \\
153 \pm 5\end{array}$ & 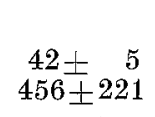 & $\begin{array}{l}37 \pm 6 \\
59 \pm 15 \mathrm{e}\end{array}$ & $\begin{array}{l}9.2 \pm 0.4 \\
6.0 \pm 0.9\end{array}$ & $\begin{array}{l}40.0 \pm 3^{\mathrm{f}} \\
20.9 \pm 5^{\mathrm{g}}\end{array}$ \\
\hline
\end{tabular}

a 5-9 Months old at beginning - each KK matched with $\mathrm{C} 57$ of same age.

b $\mathrm{C} 57 \mathrm{BL} / 6 \mathrm{~J}$ ate average $2.6 \mathrm{gm} /$ day and $\mathrm{KK}$ ate average $3.6 \mathrm{~g} /$ day.

c Insulin $250 \mu \mathrm{U} / \mathrm{ml}$ of buffer.

d $P<0.01$ compared to initial.

e $P=0.01-0.025$ compared to initial.

f $P<0.01$ compared to 0 insulin.

g $P=0.01-0.025$ compared to 0 insulin.

Adipose tissue from KK mice on a limited diet for 3 months responded to insulin in an essentially normal manner (Table 10). Tissue from ad libitum fed controls did not respond to insulin. Plasma insulins and body weights were reduced to near normal levels in the animals maintained on limited diet (Table 10). data would suggest that if animals with high blood sugars and elevated plasma insulins are required, then one may lose these traits with continued inbreeding and therefore outcrossing with $\mathrm{C} 57 \mathrm{BL} / 6 \mathrm{~J}$ 's may be necessary to maintain the required abnormalities in this strain of animals. 


\section{Discussion}

Metabolic changes in the KK mouse were not usually present until after $\mathbf{2 . 5}-\mathbf{3 . 5}$ months of age aIthough some increase in body weight, a slight increase

Table 11. Blood sugar and plasma insulin in $K K$ mice of successive generations. Original stock were received from Japan. $F_{1}$ are offspring from the original mice. Age $>3$ months

\begin{tabular}{|c|c|c|c|c|}
\hline Generation & $\begin{array}{l}\text { No. } \\
\text { tested }\end{array}$ & $\begin{array}{l}\text { No. with } \\
\text { blood sugar } \\
\text { greater than } \\
200 \mathrm{mg} \%\end{array}$ & $\begin{array}{l}\text { Plasma insu } \\
\mu U / m l \\
()=\text { No. }\end{array}$ & \\
\hline$F_{1}^{\prime}$ & 22 & 6 & - & \\
\hline$F_{2}^{\prime}$ & 39 & 18 & $\begin{array}{l}1000-2000 \\
500-1000 \\
250-500 \\
20 \text { not meas }\end{array}$ & $\begin{array}{r}(4) \\
(5) \\
(10) \\
\text { sured }\end{array}$ \\
\hline$F_{4}$ & 11 & 2 & $\begin{array}{l}250-500 \\
100-200 \\
<100\end{array}$ & $\begin{array}{l}(2) \\
(6) \\
(3)\end{array}$ \\
\hline$F_{5}$ & 19 & 1 & $\begin{array}{l}>150 \\
<100\end{array}$ & $\begin{array}{r}(1) \\
(18)\end{array}$ \\
\hline$F_{6}$ & 75 & 0 & $\begin{array}{l}>1000 \\
200-600 \\
100-200 \\
<100\end{array}$ & $\begin{array}{r}(2) \\
(5) \\
(10) \\
(58)\end{array}$ \\
\hline$F_{7}$ & 47 & 4 & $\begin{array}{l}200-400 \\
100-200 \\
<100\end{array}$ & $\begin{array}{r}(4) \\
(2) \\
(41)\end{array}$ \\
\hline$F_{8}$ & 37 & 0 & $\begin{array}{l}100-200 \\
<100\end{array}$ & $\begin{array}{r}(2) \\
(35)\end{array}$ \\
\hline $\begin{array}{l}F_{9} \text { and } F_{10} \\
\mathrm{C} 57 \mathrm{BL} / 6\end{array}$ & $\begin{array}{l}43 \\
59\end{array}$ & $\begin{array}{l}0 \\
0\end{array}$ & $\begin{array}{l}<100 \\
>100 \\
<100\end{array}$ & $\begin{array}{r}(43) \\
(1) \\
(58)\end{array}$ \\
\hline
\end{tabular}

Table 12. Blood sugars and plasma insulin of 6 th and 7 th generation of Toronto mice which were derived from $K K$ $\times C 57 B L / 6 J$

\begin{tabular}{llll}
\hline $\begin{array}{l}\text { Age } \\
\text { (weeks) }\end{array}$ & Number & $\begin{array}{l}\text { Number with } \\
\text { blood sugar } \\
>200 \mathrm{mg} \%\end{array}$ & $\begin{array}{l}\text { Plasma insulin } \\
\text { (No. mice) }\end{array}$ \\
\hline
\end{tabular}

\begin{tabular}{|c|c|c|c|c|}
\hline \multicolumn{5}{|c|}{ 6th Generation } \\
\hline $8-10$ & 22 & 4 & $\begin{array}{l}<100 \\
100-1000 \\
1000-2000\end{array}$ & $\begin{array}{r}(14) \\
(6) \\
(2)\end{array}$ \\
\hline 28 & 11 & 7 & $\begin{array}{l}<100 \\
100-1000\end{array}$ & (0) \\
\hline 33 & 8 & 5 & $\begin{array}{l}1000-2000 \\
<100 \\
100-1000 \\
1000-2000\end{array}$ & $\begin{array}{l}(7) \\
(0) \\
(2) \\
(6)\end{array}$ \\
\hline \multicolumn{5}{|c|}{ rth generation } \\
\hline $8-10$ & 69 & 4 & $\begin{array}{l}<100 \\
100-1000 \\
1000-2000\end{array}$ & $\begin{array}{r}(34) \\
(33) \\
(2)\end{array}$ \\
\hline
\end{tabular}

in plasma insulin and decreased glucose utilization by adipose tissue has been observed in the younger animals. Changes in KK mice are primarily characterized by increased plasma insulin, increased body weight, obesity, increased quantity of pancreatic insulin and the loss of response of adipose tissue (as evidenced by decreased glucose oxidation and decrease of plasma free fatty acids in fed mice) and muscle to insulin. KK mice exhibit only a mild and inconsistent hypergly. cemia in the population of animals studied. "Diabetes" probably begins in this animal strain with increased food intake which results in increased fat deposition, decreased sensitivity of adipose tissue and muscle to insulin and decreased tolerance to glucose. Support of this hypothesis is : 1 . young KK mice even though only

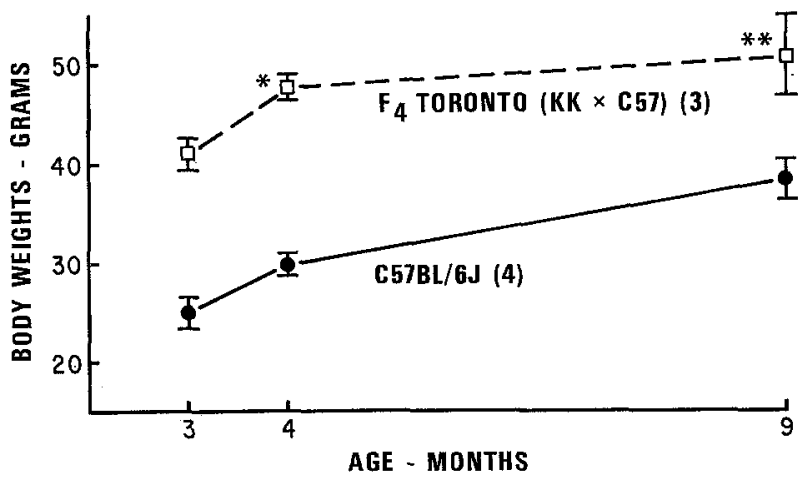

Fig. 2. Comparison of nonfasted blood sugars of C57BL/ $6 \mathrm{~J}$ and Toronto $F_{4}$ mice from $\mathrm{KK} \times \mathrm{C} 57 \mathrm{BL} / 6 \mathrm{~J}$ cross

$\mathrm{I}=$ Standard error of the mean; ()$=$ No. mice; $*=$ $P<0.05$.

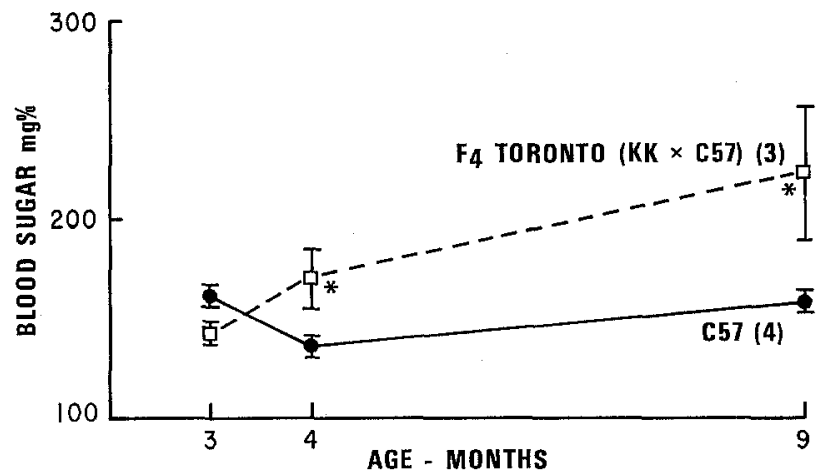

Fig. 3. Body weights of $\mathrm{C} 57 \mathrm{BL} / 6 \mathrm{~J}$ and $F_{4}$ Toronto mice from $\mathrm{KK} \times \mathrm{C} 57 \mathrm{BL} / 6 \mathrm{~J}$ cross

$\mathbf{I}=$ Standard error of the mean; $*=P<0.001 ; * *=$ $P<0.05 ;()=$ No. mice.

slightly heavier than normal do not exhibit much increased insulin levels but adipose tissue is less responsive to insulin; 2. when body weight increases sufficiently, plasma insulin increases and a marked insensitivity of adipose tissue to insulin develops, and 3 . if body weight is restored to normal in older KK mice, insulin levels are reduced and response of adipose tissue to insulin is restored. The reason that blood suggar is essentially normal in KK mice even though peripheral tissues are not capable of using glucose at a normal rate might be explained if gluconeogenic enzymes of the livers of KK mice were under the control of the circulating insulin; however, sufficient data are not 
available on this point. The panereas of the KK mouse apparently adapts to increased demands placed upon it and secretes sufficient insulin to maintain relatively normal control of blood sugar during periods when increased insulin is demanded. Supporting this hypothesis are observations that islet hypertrophy with increased pancreatic insulin have been reported by Nakamura [2] and confirmed in the present studies.

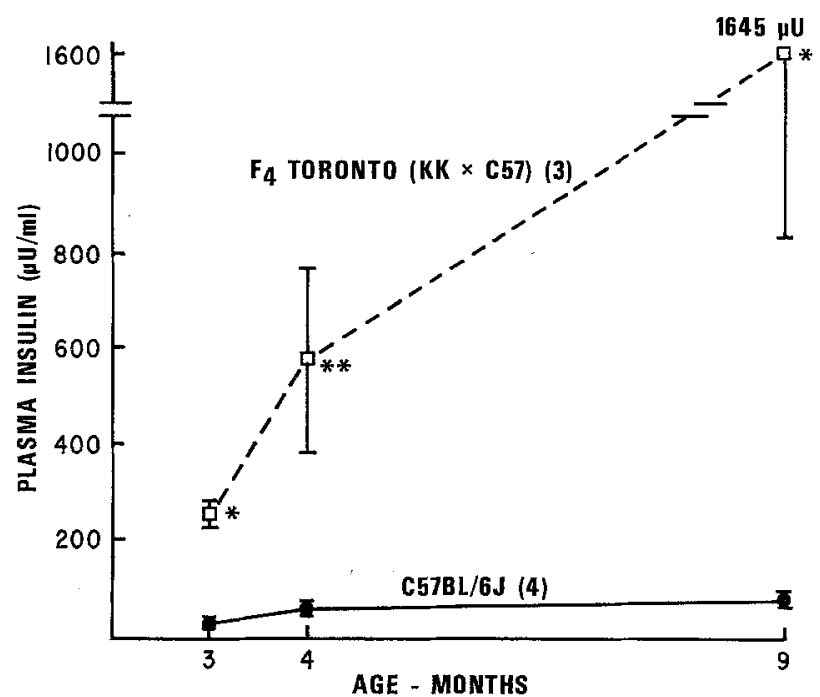

Fig. 4. Plasma insulins of $\mathrm{C} 57 \mathrm{BL} / 6 \mathrm{~J}$ and $F_{4}$ Toronto mice from $\mathrm{C} 57 \mathrm{BL} / 6 \mathrm{~J} \times \mathrm{KK}$ cross

$\mathrm{I}=$ Standard error of the mean; $(\quad)=$ No. mice; $*=$ $P<0.001 ; * *=P<0.05$.

It is of interest that in successive inbred generations of KK mice there was a decreased number of animals with elevated blood sugars and plasma insulins. These observations would tend to support the hypothesis that during inbreeding of the KK mice in the Upjohn colony there was inadvertent selection against the genes or genetic conditions responsible for the manifestations of abnormalities. Inbred mice from a cross between KK's and C57 BL/6J's at the University of Toronto laboratories exhibited increased numbers of mice with elevated blood sugars and plasma insulins.
Analysis of data from animals bred from $F_{4}$ Toronto hybrids show a high number with elevated insulins, more than $20 \%$ of these animals show blood sugars greater than $200 \mathrm{mg} \%$ and greater than $50 \%$ with elevated plasma insulins. The reason for this restoration of abnormalities seen in the original $\mathrm{KK}$ mouse by outbreeding with the C57 BL/6J's is not clear at the present time and further studies are being carried out in the University of Toronto and Upjohn laboratories in an effort to understand the metabolic abnormalities of this strain of mouse.

Acknowledgements. Thanks to Dr. L. Butler and Mrs. Muriel Harris for the generous supplies of Toronto mice

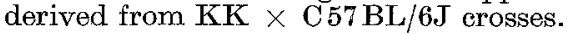

\section{References}

1. Butler, L.: A comparison of the mode of inheritance of diabetes in the Chinese hamster and the $\mathrm{KK}$ mouse. Diabetologia. 6, 163-167 (1970)

2. Gerritsen, G.C., Dulin, W.E.: Characterization of diabetes in the Chinese hamster. Diabetalogia 3, 7484 (1967).

3. - - Effect of a new hypoglycemic agent, 3,5 dimethyl pyrazole on carbohydrate and free fatty acid metabolism. Diabetes 14, 507-515 (1966).

4. Kondo, K.K., Nozawa, T., Tomida T., Ezaki K.: Inbred strains resulting from Japanese mice. Bull. Exp. Animals 6, $107-112$ (1957).

5. Morgan, C.R., Lazarow, A.: Immunoassay of insulin, two antibody system. Diabetes 12, 115-126 (1963).

6. Nakamura, M.: A diabetic strain of the mouse. Proc. Japan. Acad. 38, 348-352 (1962).

7. - Yamada, K.: Studies on a diabetic (KK) strain of mouse. Diabetologia $3,212-221$ (1967).

8. - - A further study of the diabetic (KK) strain of the mouse. $F_{1}$ and $F_{2}$ offsprings of the cross between KK and C57BL. Proc. Japan. Acad. 39, 489-493 (1963)

9. Riley, V.: Adaptation of orbital bleeding technique to rapid serial blood studies. Proc. Soc. exp. Biol. Mod. 104, $751-754$ (1960).

10. Vallance-Owen, J., Hurlock, B.: Estimation of plasma insulin by the rat diaphragm method. Lancet 1961 I, $806-807$.

W.E. Dulin, M. D.

Diabetes Research

The Upjohn Company

Kalamazoo, Michigan, USA 